\title{
Additional cost of end-stage kidney disease in diabetic patients according to renal replacement therapy modality: a systematic review
}

\author{
Isabella Vanorio-Vega ${ }^{1,2^{*}}$ (D), Panayotis Constantinou ${ }^{1}$ (D), Philippe Tuppin ${ }^{1}$ (D) and Cécile Couchoud ${ }^{2}$ (D)
}

\begin{abstract}
The prevalence of end-stage kidney disease (ESKD) is growing worldwide; the survival of these patients requires renal replacement therapy (RRT, a complex and costly treatment). Over $20 \%$ of the patients that start RTT had diabetes. Limited evidence on the effect of comorbidities on the cost of RRT exists. This review summarizes the available evidence on the effect of diabetes mellitus (DM) on the cost of RRT. Electronic databases were searched using key words that combined RRT with DM and cost. References were identified with title, abstract, and full-text screening. The studies included were published in English and presented data on the cost of RRT in ESKD patients with comparison between DM status. Seventeen studies were included in this review. The crude and adjusted cost of care estimates for patients on dialysis was generally higher for DM patients. The cost of care of ESKD patients differed according to various treatment modalities and these differences, mainly driven by inpatient costs. Overall, we found an increased cost of RRT care in patients with DM regardless of the type of treatment. Future analysis of the effects of multiple comorbidities should be considered to better understand the effect of DM on the cost of RRT.
\end{abstract}

Keywords: Cost, Diabetes, Dialysis, Renal replacement therapy, Renal transplant

\section{Background}

The prevalence of end-stage kidney disease (ESKD) is continuing to increase worldwide. Long-term survival of these patients is dependent on renal replacement therapy (RRT) (hemodialysis [HD], peritoneal dialysis [PD], and/or kidney transplant). In Europe, over $20 \%$ of the RTT incident cases had diabetes, over $10 \%$ a cardiovascular disease, and over $50 \%$ are 65 years old or older [1]. ESKD has been recognized as a public health concern due to the financial and human burden, the complexity

\footnotetext{
* Correspondence: Isabella.vanoriovega@assurance-maladie.fr

${ }^{1}$ Direction de la stratégie des études et des statistiques, Caisse nationale de I'assurance maladie (CNAM), Avenue du Professeur André Lemierre, 75020 Paris, France

${ }^{2}$ Agence de la biomédecine, 1 Avenue du Stade de France, 93212 Saint-Denis, France
}

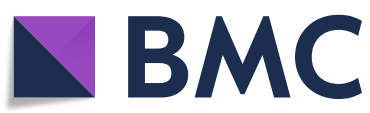

(c) The Author(s). 2021 Open Access This article is licensed under a Creative Commons Attribution 4.0 International License, which permits use, sharing, adaptation, distribution and reproduction in any medium or format, as long as you give appropriate credit to the original author(s) and the source, provide a link to the Creative Commons licence, and indicate if changes were made. The images or other third party material in this article are included in the article's Creative Commons licence, unless indicated otherwise in a credit line to the material. If material is not included in the article's Creative Commons licence and your intended use is not permitted by statutory regulation or exceeds the permitted use, you will need to obtain permission directly from the copyright holder. To view a copy of this licence, visit http://creativecommons.org/licenses/by/4.0/ The Creative Commons Public Domain Dedication waiver (http://creativecommons.org/publicdomain/zero/1.0/) applies to the data made available in this article, unless otherwise stated in a credit line to the data.

of care, and the growing prevalence of the disease [2]. In Europe, the number of prevalent patients increased from 641.6 per million population (pmp) in 1997 to $823 \mathrm{pmp}$ in 2016 [3, 4]. This increase has been attributed to a surge of the prevalence of conditions that lead to chronic kidney disease (CKD), such as diabetes, cardiovascular disease, and older age [5].

In the USA, $47 \%$ of incident ESKD patients are attributed to diabetes [6]. Total spending for ESKD patients accounts for $7 \%$ of the Medicare budget and allocated to $1 \%$ of the population [7]. In France, $22.2 \%$ of the ESKD incident patients are attributed to diabetes [6]. The cost of RRT represented 3\% of the total budget of the French national health insurance fund in 2013 and served less than 1\% of the population [8]. Studies have found that the most clinically 
effective and cost-effective treatment modality is kidney transplantation [9]. However, transplant availability is limited, and this modality is not suitable for all ESKD patients, particularly patients with one or several comorbidities [10], which limit the eligibility for kidney transplantation and self-care dialysis. Multiple comorbidities have been associated with an increased pattern of cost [11]; nonetheless, the available evidence remains limited.

Diabetes mellitus (DM) is recognized as the primary cause of ESKD in the USA, Europe, and other regions of the world, with a prevalence ranging between 23 and $39 \%$ in ESKD patients $[1,12,13]$. Diabetic patients on HD have a poorer quality of life, an increased risk of developing/worsening of cardiovascular disease, neurological diseases, and an increased mortality [14-16]. As the prevalence of diabetes is increasing worldwide [17], it is expected that a greater number of patients will develop diabetic chronic kidney disease and eventually ESKD [18]. In this narrative review, we will summarize the available evidence on the effect of DM on the cost of RRT according to the treatment modality.

\section{Methods}

\section{Literature search}

Seven electronic databases were searched from data inception to mid-February 2018 with no time or methodology restrictions through focused and highly sensitive search strategies: NHS Economic Evaluation Database, Health Technology Assessment (via EBM Reviews), Embase (via the Ovid platform), EconLit (via EBSCO), Cochrane library, APAIS Health (via Informit), and Medline (search from inception to July 2020). Databases were searched for medical subject headings $(\mathrm{MeSH})$ and keywords, combining terms related to dialysis or kidney transplantation with terms related to DM and terms related to cost information ("cost", "expenditure", "costing", "cost evaluation"). A manual search for grey literature was conducted to retrieve government documents or commission reports.

\section{Inclusion criteria}

This review included studies in English reporting data on costs in ESKD patients treated by RRT (HD and/or $\mathrm{PD}$ and/or kidney transplantation) and comparing patients with DM and patients without DM, regardless of the type of diabetes.

\section{Exclusion criteria}

Studies that did not report separate costs for DM patients, studies that reported costs for combined comorbidities, non-primary studies (review articles, commentaries, letters, editorials), and studies including only post-transplant DM were not included.

\section{Study selection}

Titles and abstracts were screened, removing irrelevant records (either not related to our topic or irrelevant study design (reviews or non-original data). Full texts were sourced for the remaining records, and their eligibility was assessed for inclusion. We extracted the following information: first author, year of publication, setting (i.e., country), study design, definition of DM, type of dialysis, data sources, perspective, currency, cost, cost categories, time period considered for calculation of costs. A narrative approach was used to synthesize the current findings.

\section{Cost assessment}

To assess and categorize costs, we will use the terminology adopted by the French National Authority for Health to evaluate medico-economic strategies in the management of end-stage kidney disease. Costs related to consumption of hospital, ambulatory care, transportation, health program, and prescribed medications will be categorized as direct costs. Indirect costs refer to the impact of the disease on an individual's ability or not to work as a result of reduced survival [19]. A top-down estimation refers to the estimation of costs using overall cost of a service of component; consequently, the estimation of unitary costs when using this method is the average cost; therefore, insensitive to between-patient variability. A bottom-up approach provides detailed information about the cost components per patient and identifies patient-specific unit costs. Person-based methods can more accurately assess and adjust for between-patient variability [20,21].

\section{Appraisal and quality assessment}

Quality assessment used the Consolidated Health Economic Evaluation Reporting Standards (CHEERS) checklist. This scale considers three major issues: selection (source of the population and its representativeness, sample size, missing values, exposure analysis), comparability (most important factor, other factors), and outcome (evaluation, statistical test).

\section{Results \\ Literature search}

The database searches performed in 2018 and 2020 identified 1416 records. After removing duplicate and irrelevant articles, 43 articles were submitted to fulltext review. No studies of interest were identified in the grey literature. Twenty-five of these 43 references were excluded, as they did not report costs for diabetic patients or presented the costs of combined stages of CKD. At the end of the process, we identified 18 references (Fig. 1) [11, 22-38] (corresponding 


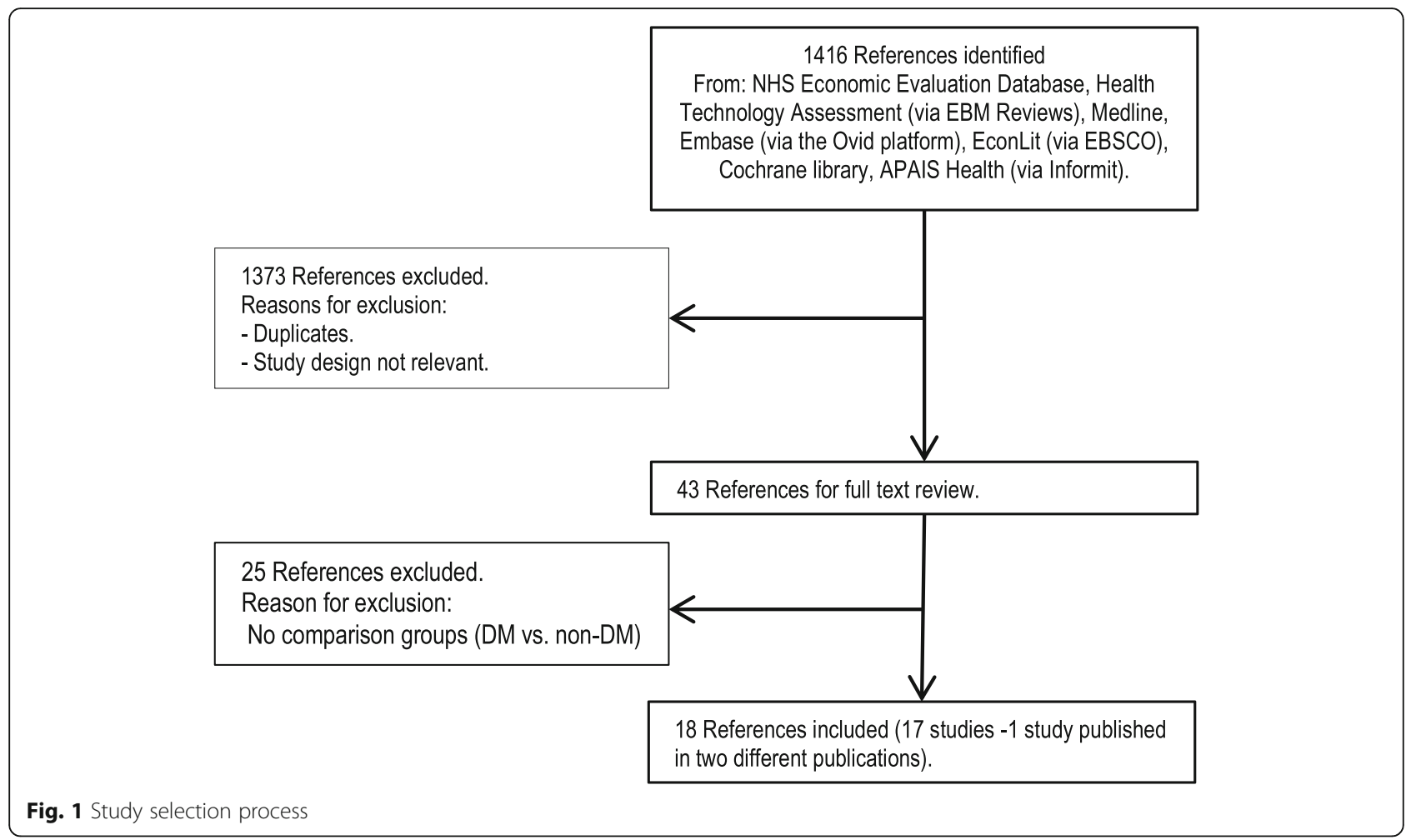

to 17 studies, as one study was published in 2 parts $[11,22])$.

\section{Study characteristics}

The 17 studies comprised no randomized controlled trials, 9 cohort studies [22, 24, 27, 29,32-34, 36, 37], and 8 cross-sectional studies [11, 22, 25, 26, 28, 30, 31, 35, 38] (see Tables 1 and 2 for characteristics of the included studies). Four studies included incident patients [11, 22, 29, 32, 33], 2 studies included incident and prevalent patients $[23,34]$, and the rest of the studies included prevalent patients [24-28, 30,31, 35-38]. Only 6 studies included transplanted patients [11, 29, 30, 35-37]. One article considered patients that were diagnosed with DM before and after kidney transplantation [37]. The proportion of diabetic patients ranged from 18 to $49 \%$ in the different groups and subgroups, except one article where DM patients were matched to non-DM [26].

\section{Resource use and costs}

All of the studies included in this review reported direct cost of care; none of the studies reported indirect cost of RRT. Three studies reported bottom-up cost estimates [24, $25,28], 1$ study reported a mix of bottom-up and top-down estimates [27], and the remaining studies used a top-down approach. Ten studies adopted an insurance perspective [11, 22, 24, 26, 28, 30, 31, 33, 34, 36], 4 studies adopted a provider perspective [25, 29, 32, 35], and 2 studies adopted a societal perspective $[23,27]$. Five studies were based on national databases $[11,22,24,30,37]$. The types of costs reported in the studies in this review included inpatient in 7 studies [11, 22, 24, 26, 28, 30,31,35], outpatient in 6 studies [11, 22, 24, 28, 30,31,33], reimbursement in 4 studies [32, $33,36,37]$, transportation in 4 studies [27, 30, 31, 35], drugs in 3 studies [30, 35, 38], and dialysis procedure in 2 studies $[31,34]$. The following were reported in individual studies: social services and patient out-of-pocket expenditure [23], amount paid by healthcare providers [25], caregiver costs [27], laboratory tests [35]. Six studies presented adjusted results $[11,22,23,27,31,32]$.

\section{Quality appraisal of the studies}

The overall study quality assessed by the CHEERS checklist was moderate to low, details in Table 2. Almost half of the studies included less than 400 patients, while the remaining studies comprised populations ranging between 1146 and 290,537 patients. Most of the studies are not representative of the general population, none of the studies addressed missing data, and only a few studies considered additional factors. Heterogeneous variables selected to adjust for confounders across studies (age, gender, comorbidities, income, and other variables) and the method of identification of DM varied (by medication consumption or previous medical records).

\section{Impact of DM on costs}

In the group of studies that reported cost analysis using crude results, 2 studies did not find any statistical 


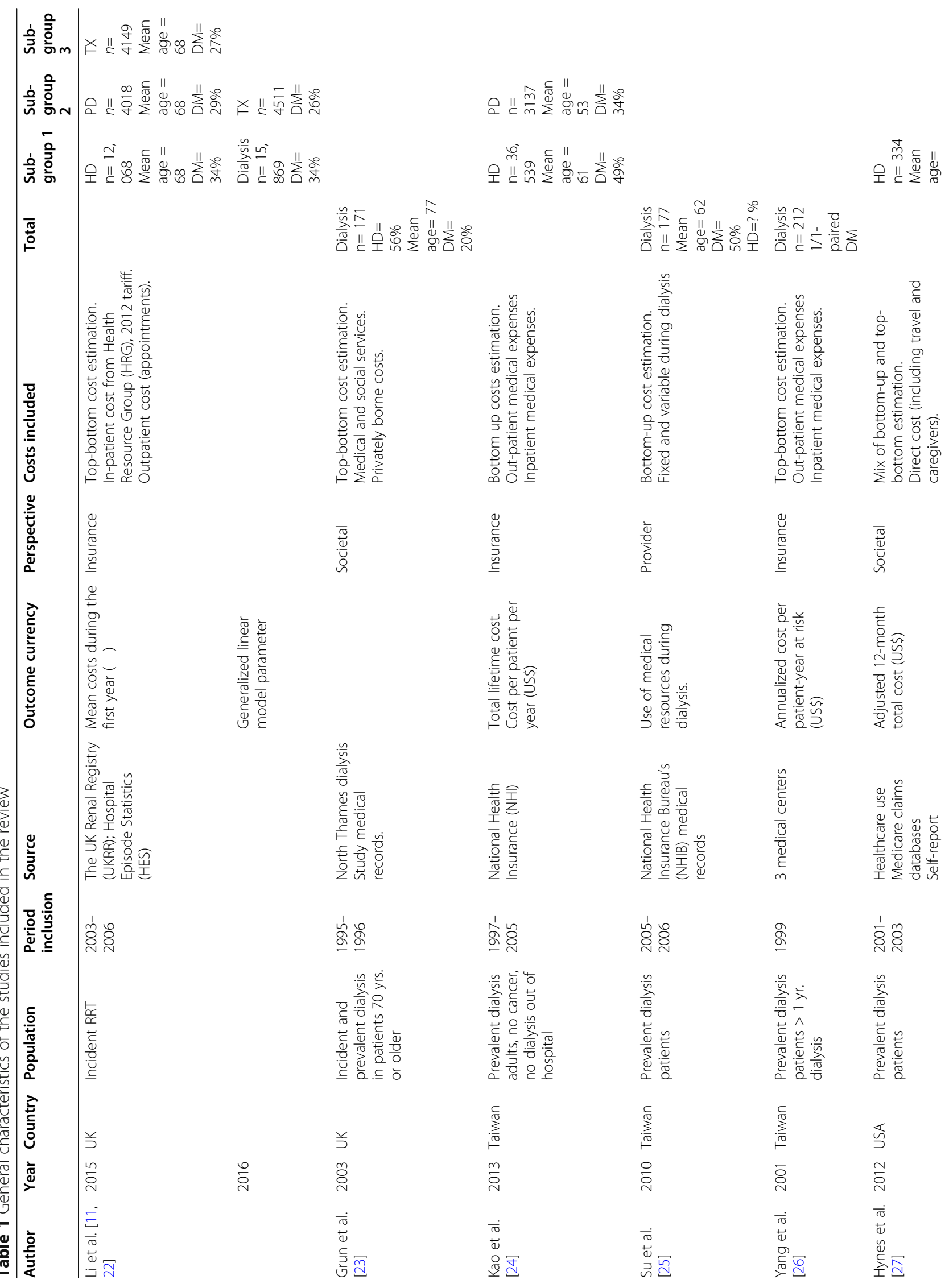




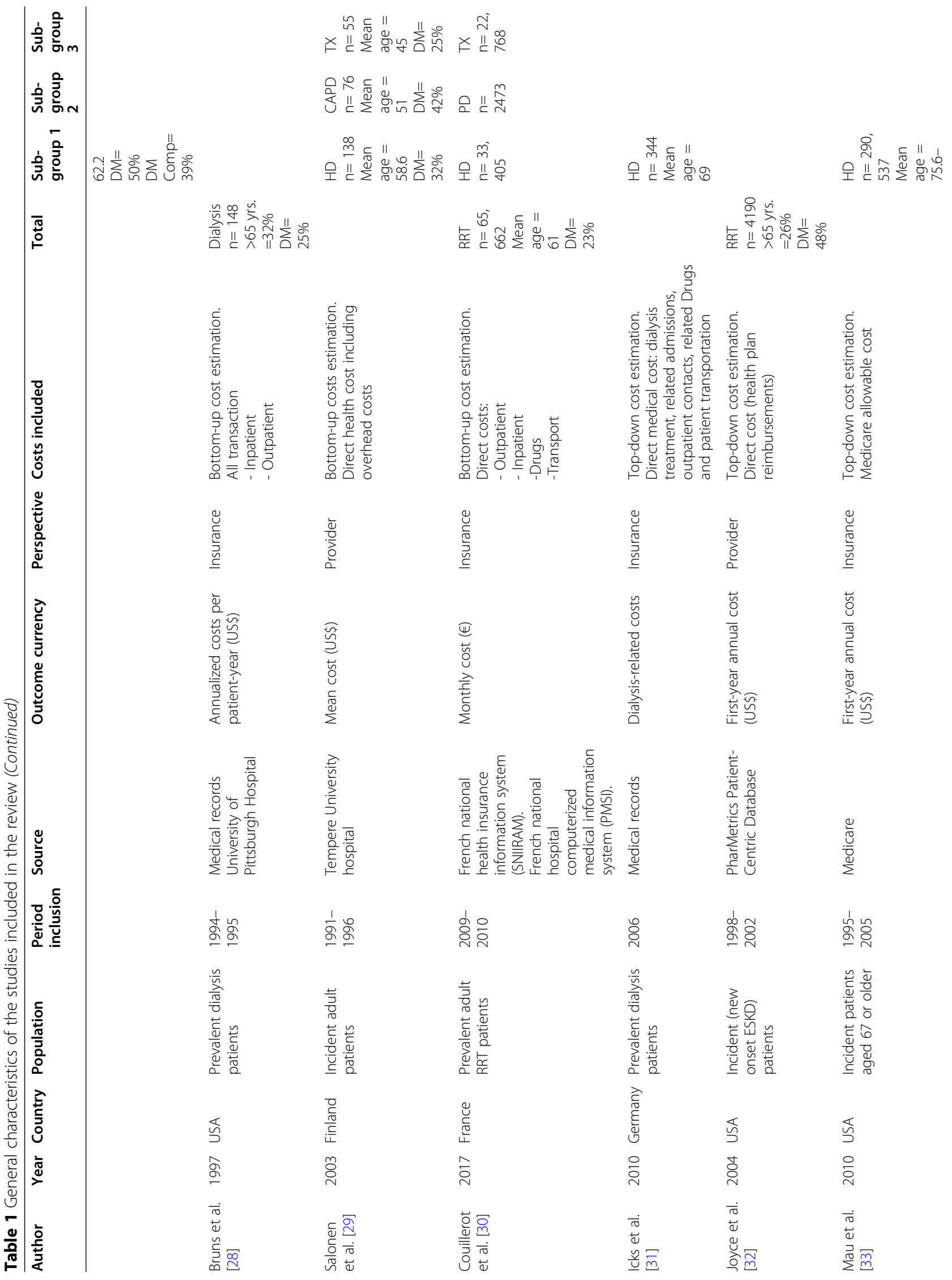




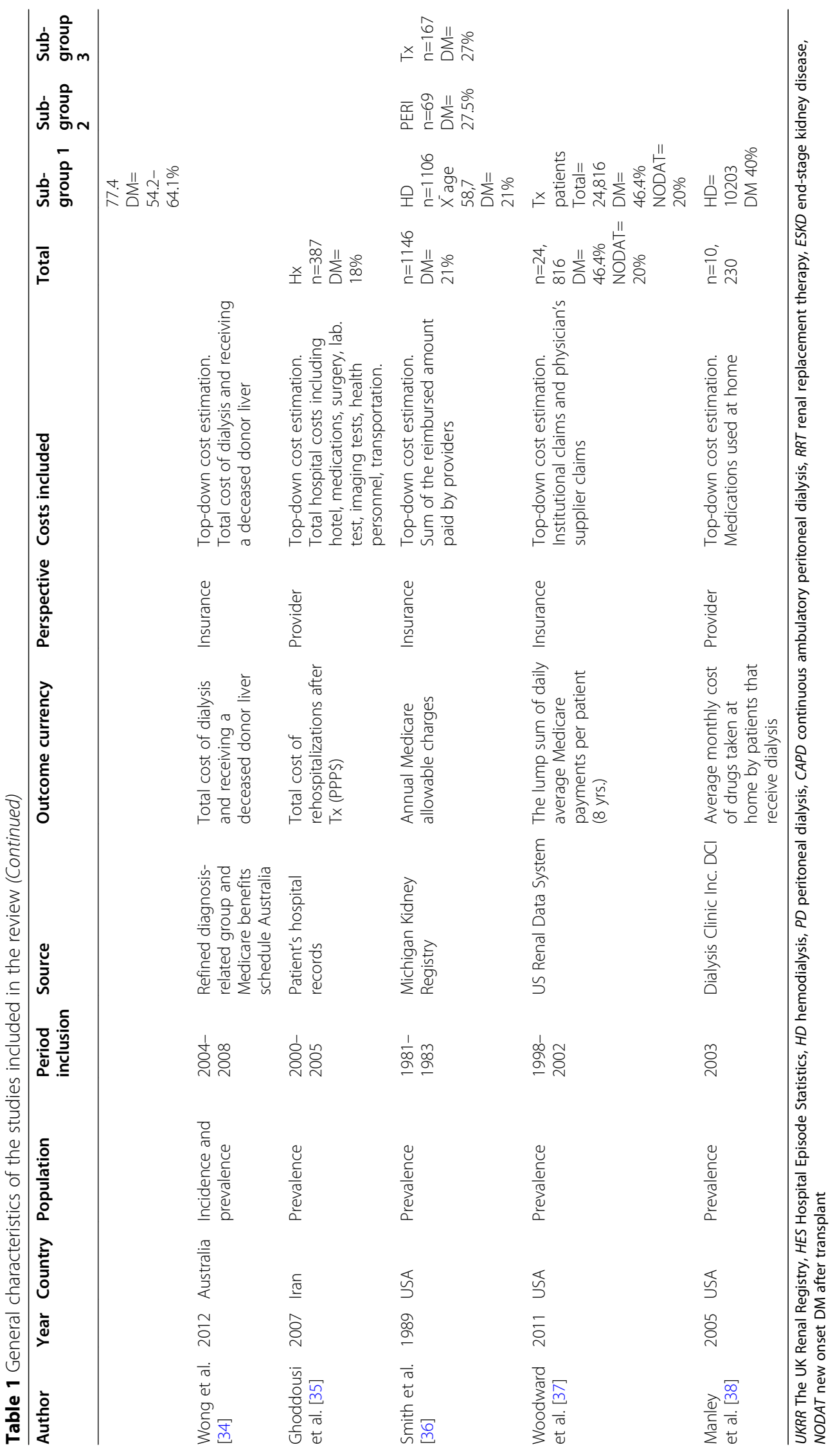




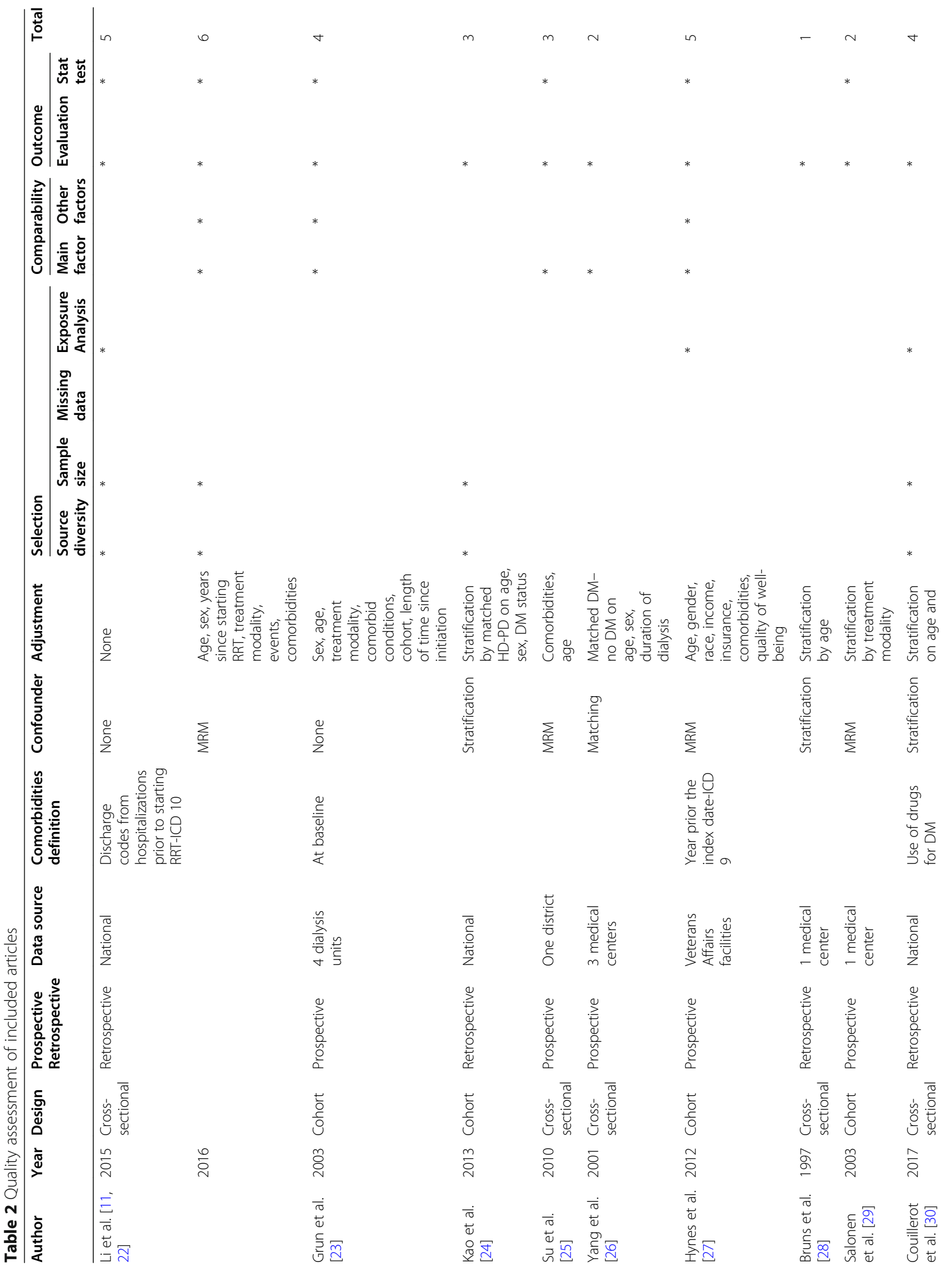




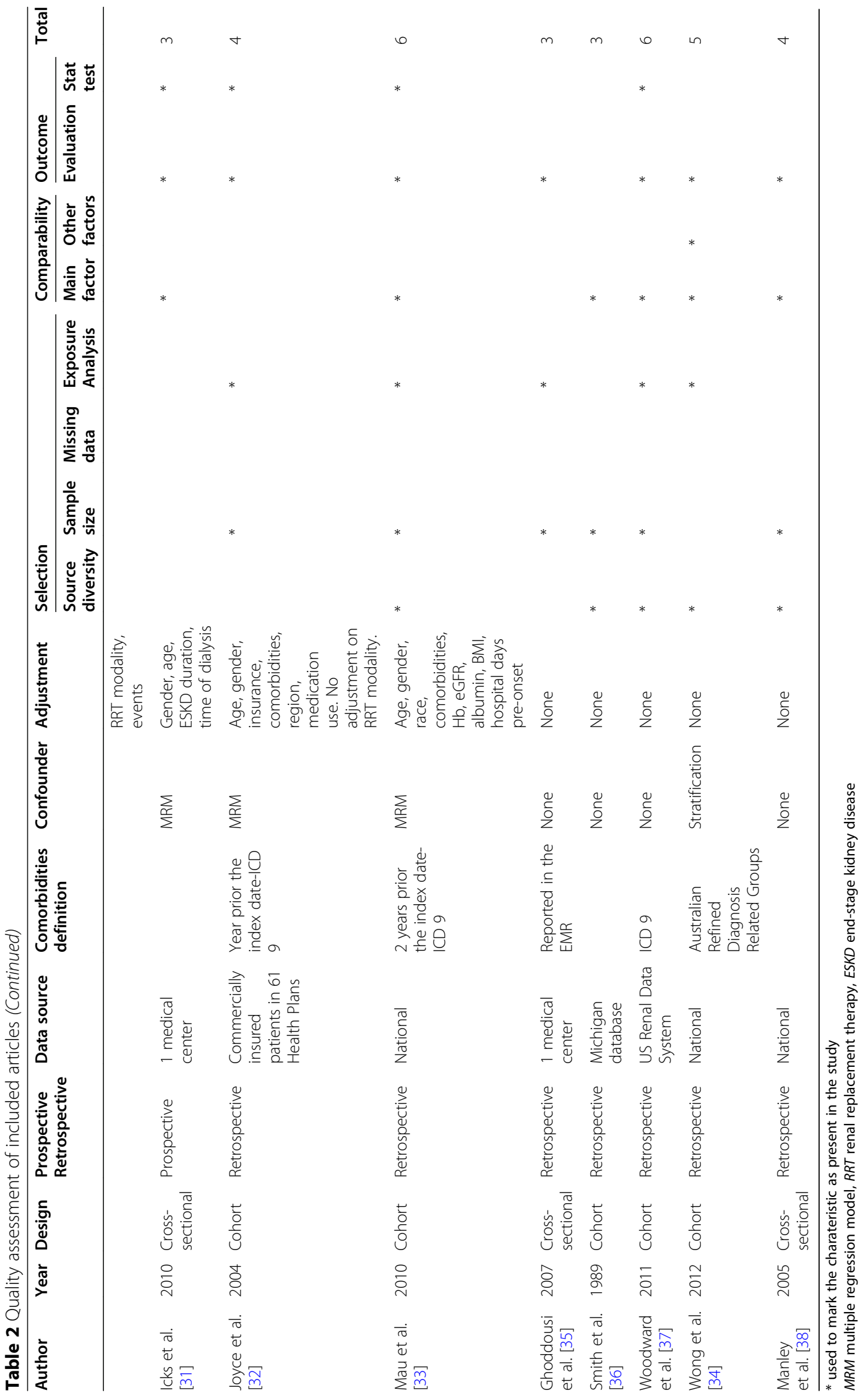


differences in terms of crude mean cost between patients with or without DM receiving dialysis (HD and PD grouped together) (Table 3) [23, 25]. One study found a $23 \%$ difference for the cost per patient-year, varying according to age from $61 \%$ in the $65-74$ years age-group vs $-22 \%$ in DM patients $\geq 75$ years [28]. One study found a $12 \%$ difference in total cost per patient-year, mainly explained by the difference in terms of utilization of resources during hospitalization between non-DM and DM patients [26]. The last study to report differences within the HD+PD group showed increased annual costs among DM patients for all comparator groups ranging from 17 to $44 \%$, except for the annual costs related to at-home continuous ambulatory peritoneal dialysis training (CAPDTR) that were 3\% lower among DM patients [36].

Table 4 contains details of the studies that reported HD and PD cost estimates separately. In the HD group, four studies found a higher cost for DM patients between 4 and $32 \%$, regardless of the comparator used or the age group or the treatment modality [11, 29, 30, 38]. Among PD patients, three studies found a higher cost in DM patients, between 4 and $52 \%$, regardless of the comparator used or the age group or the type of PD [11, 29, 30]. One study found a lower total lifetime cost in DM patients with -48 and $-42 \%$ for $\mathrm{HD}$ and $\mathrm{PD}$. The differences expressed in terms of life years were 23 and $32 \%$, respectively [24].

In transplanted patients (Table 5), four studies found a higher cost in DM patients regardless of the comparator ranging between 14 and 100\% [11, 30, 35, 37]. Salonen et al. reported a lower cost for DM in the comparator group for the first 6 months $(-4 \%)$ and during the second year after transplant $(-10 \%)$ [29]. Two studies presented cost estimates for all RRT patients, and both reported higher costs for DM patients, ranging between 5 and $50 \%[32,34]$.

Six studies presented adjusted cost analyses (Table 6), and 3 of these studies reported significant results suggesting a positive relationship between DM and increased cost [22, 32]. Three studies, based on relatively small sample sizes, did not find any statistical association between DM and costs [23, 27, 31].

\section{Discussion}

Our narrative review shows for the first time to our knowledge the different costs of care between DM and non-DM patients by type of RRT. This review found that higher costs are generally reported for patients with DM in RRT. The costs most commonly reported were inpatient costs and outpatient costs. The difference between DM and non-DM patients was observed

Table 3 Crude cost estimate reported in dialysis patients (HD + PD)

\begin{tabular}{|c|c|c|c|c|c|c|c|}
\hline Author & Year & comparator & Stratification & Value of non-DM (SD) & Value of DM (SD) & Diff & $\mathrm{p}$ \\
\hline Grun et al. [23] & 2003 & Mean cost per day (£) & None & $68.5(30.5)$ & $68.1(28.1)$ & $-1 \%$ & 0.94 \\
\hline Su et al. [25] & 2010 & Dialysis cost (NT) & None & $1467.53(220.9)$ & $1481.6(209.13)$ & $1 \%$ & 0.664 \\
\hline \multirow[t]{7}{*}{ Yang et al. [26] } & 2001 & Total cost (US\$/patient-year) & None & 24,146 & 26,988 & $12 \%$ & \\
\hline & & Outpatient (US\$/patient-year) & None & 22,820 & 22,311 & $-2 \%$ & \\
\hline & & Dialysis and EPO & None & 21,209 & 19,841 & $-6 \%$ & \\
\hline & & Other clinic & None & 1611 & 2470 & $53 \%$ & \\
\hline & & Hospitalization (US\$/patient-year) & None & 1325 & 4677 & $253 \%$ & \\
\hline & & Dialysis and EPO & None & 409 & 1093 & $167 \%$ & \\
\hline & & Others & None & 916 & 3584 & $291 \%$ & \\
\hline \multirow[t]{5}{*}{ Bruns et al. [28] } & 1997 & Costs per patient-year (\$) & All & 55,581 & 68,228 & $23 \%$ & \\
\hline & & & $20-44$ & 48,927 & 51,884 & $6 \%$ & \\
\hline & & & $45-64$ & 65,707 & 72,643 & $11 \%$ & \\
\hline & & & $65-74$ & 48,062 & 77,418 & $61 \%$ & \\
\hline & & & $\geq 75$ & 59,594 & 46,746 & $-22 \%$ & \\
\hline \multirow[t]{6}{*}{ Smith et al. [36] } & 1989 & Annual charges HD in centers & None & 23,470 & 27,463 & $17 \%$ & \\
\hline & & Annual charges PERI in centers & None & 22,529 & 26,486 & $18 \%$ & \\
\hline & & Annual charges CAPDTR & None & 18,408 & 17,879 & $-3 \%$ & \\
\hline & & Annual charges CAPDH & None & 22,753 & 29,435 & $29 \%$ & \\
\hline & & Annual charges Other & None & 28,342 & 40,779 & $44 \%$ & \\
\hline & & Weighted average & None & 24,976 & 29,671 & $19 \%$ & \\
\hline
\end{tabular}


Table 4 Crude cost estimate reported in HD and PD separate groups.

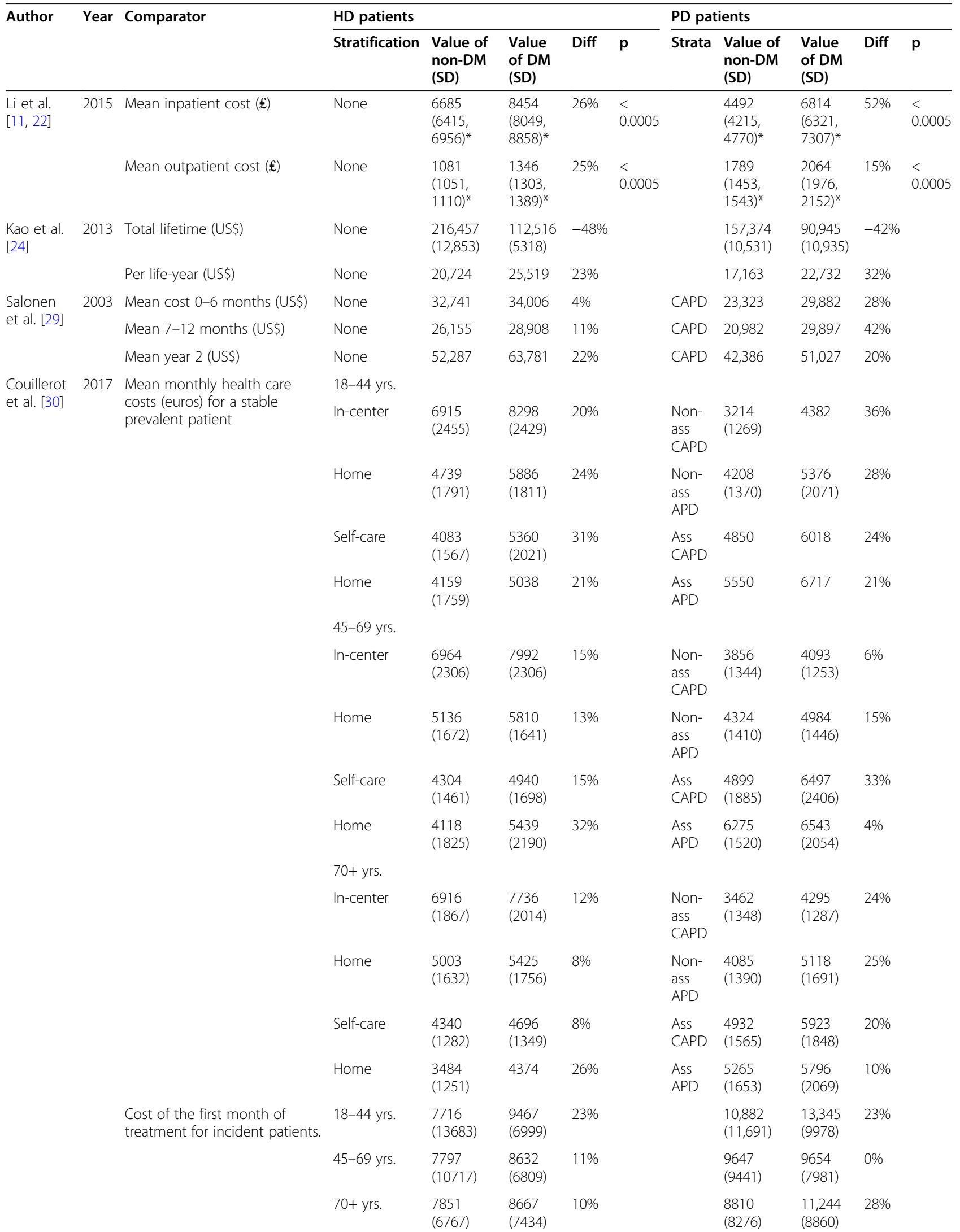


Table 4 Crude cost estimate reported in HD and PD separate groups. (Continued)

\begin{tabular}{|c|c|c|c|c|c|c|c|c|c|c|c|c|}
\hline \multirow[t]{2}{*}{ Author } & \multirow[t]{2}{*}{ Year } & \multirow[t]{2}{*}{ Comparator } & \multicolumn{5}{|l|}{ HD patients } & \multicolumn{5}{|c|}{ PD patients } \\
\hline & & & Stratification & $\begin{array}{l}\text { Value of } \\
\text { non-DM } \\
\text { (SD) }\end{array}$ & $\begin{array}{l}\text { Value } \\
\text { of DM } \\
\text { (SD) }\end{array}$ & Diff & $p$ & Strata & $\begin{array}{l}\text { Value of } \\
\text { non-DM } \\
\text { (SD) }\end{array}$ & $\begin{array}{l}\text { Value } \\
\text { of DM } \\
\text { (SD) }\end{array}$ & Diff & $p$ \\
\hline Manley & 2005 & $\begin{array}{l}\text { Monthly cost of ambulatory } \\
\text { medications. }\end{array}$ & None & $\begin{array}{l}571.04 \\
(287.36)\end{array}$ & $\begin{array}{l}691.04 \\
(271.59)\end{array}$ & $21 \%$ & & & & & & \\
\hline
\end{tabular}

*95\% CI limits

CAPD continuous ambulatory peritoneal dialysis; Non-ass CAPD non-assisted CAPD, Ass CAPD assisted CAPD

regardless of the treatment modality (dialysis or transplantation) and was mainly driven by the higher costs of hospitalization.

The results should be interpreted cautiously, 8 of the studies were published over 10 years ago, and there are numerous methodological pitfalls the observational studies included. A quality score higher than 5 was observed for only 3 studies. Thirteen studies were based on local databases and were less representative of the general population. Six studies adjusted for patient

Table 5 Crude cost estimate reported in transplanted and unspecified RRT patients:

\begin{tabular}{|c|c|c|c|c|c|c|c|}
\hline Author & Year & Comparator & Stratification & $\begin{array}{l}\text { Value of } \\
\text { non-DM (SD) }\end{array}$ & $\begin{array}{l}\text { Value of } \\
\text { DM (SD) }\end{array}$ & Diff & $p$ \\
\hline \multicolumn{8}{|c|}{ Transplanted patients } \\
\hline \multirow[t]{2}{*}{$\begin{array}{l}\text { Li et al. [11, } \\
\text { 22] }\end{array}$} & 2015 & Mean inpatient cost (£) & None & $\begin{array}{l}3626(3439 \\
3813)^{*}\end{array}$ & $\begin{array}{l}5921 \\
(5499, \\
6343)^{*}\end{array}$ & $63 \%$ & $<0005$ \\
\hline & & Mean outpatient cost (£) & None & $\begin{array}{l}3963(3890, \\
4036)^{*}\end{array}$ & $\begin{array}{l}4520 \\
(4376 \\
4665)^{*}\end{array}$ & $14 \%$ & $<.0005$ \\
\hline \multirow{3}{*}{$\begin{array}{l}\text { Salonen } \\
\text { et al. [29] }\end{array}$} & 2003 & Mean cost 0-6 months (US\$) & None & 38,946 & 37,299 & $-4 \%$ & \\
\hline & & Mean cost 7-12 months (US\$) & None & 7216 & 8497 & $18 \%$ & \\
\hline & & Mean cost 2nd year (US\$) & None & 11,972 & 10,802 & $-10 \%$ & \\
\hline \multirow[t]{3}{*}{$\begin{array}{l}\text { Couillerot } \\
\text { et al. [30] }\end{array}$} & 2017 & $\begin{array}{l}\text { Mean monthly health care costs (euros) fort a stable prevalent } \\
\text { patient }\end{array}$ & 18-44 years & $1043(1188)$ & $\begin{array}{l}2091 \\
(1998)\end{array}$ & $100 \%$ & \\
\hline & & & $45-69$ years & $1075(1065)$ & $\begin{array}{l}1640 \\
(1337)\end{array}$ & $53 \%$ & \\
\hline & & & $70+$ years & $1038(888)$ & $\begin{array}{l}1475 \\
(1129)\end{array}$ & $42 \%$ & \\
\hline $\begin{array}{l}\text { Ghoddousi } \\
\text { et al. [35] }\end{array}$ & 2007 & Total cost (PPP \$ rehospitalization) & None & $\begin{array}{l}863.93 \\
(1165.2)\end{array}$ & $\begin{array}{l}1261.98 \\
(1930.5)\end{array}$ & $46 \%$ & \\
\hline \multirow{6}{*}{$\begin{array}{l}\text { Smith et al. } \\
{[36]}\end{array}$} & 1989 & Year of transplant annual charges LTRAN & None & 41,553 & 46,797 & $13 \%$ & \\
\hline & & Year of transplant annual charges CTRAN & None & 42,074 & 61,493 & $46 \%$ & \\
\hline & & Year of transplant annual charges FTRAN & None & 58,672 & 63,670 & $9 \%$ & \\
\hline & & Year after transplant annual charges LTRAN & None & 3836 & 4320 & $13 \%$ & \\
\hline & & Year after transplant annual charges CTRAN & None & 5696 & 8325 & $46 \%$ & \\
\hline & & Year after transplant annual charges FTRAN & None & 47,057 & 50,584 & $7 \%$ & \\
\hline \multirow[t]{2}{*}{$\begin{array}{l}\text { Woodward } \\
\text { et al. [37] }\end{array}$} & 2011 & $\begin{array}{l}\text { DM before transplant. Cumulative cost per patient from } 3 \text { years } \\
\text { before transplant to } 5 \text { years after transplant }\end{array}$ & None & 114,686 & 162,048 & $29 \%$ & \\
\hline & & $\begin{array}{l}\text { NODAT before transplant. Cumulative cost per patient from } 3 \\
\text { years before transplant to } 5 \text { years after transplant }\end{array}$ & None & 114,686 & 146,915 & $22 \%$ & \\
\hline \multicolumn{8}{|l|}{ RRT } \\
\hline $\begin{array}{l}\text { Joyce et al. } \\
\text { [32] }\end{array}$ & 2004 & Annual cost for the 12 months post onset of ESKD (\$) & None & 57,249 & 86,081 & $50 \%$ & \\
\hline \multirow{2}{*}{$\begin{array}{l}\text { Wong et al. } \\
{[34]}\end{array}$} & 2012 & Total costs (\$) & 45 years old & 119,329 & 136,677 & $13 \%$ & \\
\hline & & Total costs (\$) & 60 years old & $143,004.98$ & $151,168.29$ & $5 \%$ & \\
\hline
\end{tabular}


Table 6 Adjusted cost estimations of patients receiving RRT (DM and non-DM patients)

\begin{tabular}{|c|c|c|c|c|c|}
\hline Author & Year & Stratification & Comparator & Adjusted results $(\$, £, €(95 \% \mathrm{Cl})$ & p-value \\
\hline \multicolumn{6}{|l|}{ TX patients } \\
\hline \multirow[t]{2}{*}{ Li et al. [22] } & 2016 & None & $\begin{array}{l}\text { Increase in mean annual costs ( } \$, G L M \text { coefficient) for } \\
\text { inpatient GLM }\end{array}$ & $1046(734,1359)$ & $<0.05$ \\
\hline & & & $\begin{array}{l}\text { Increase in mean annual costs (GLM coefficient) for } \\
\text { outpatient GLM }\end{array}$ & $593(515,671)$ & $<0.05$ \\
\hline \multicolumn{6}{|c|}{ Dialysis patients (HD + PD) } \\
\hline \multirow[t]{2}{*}{ Li et al. [22] } & 2016 & None & $\begin{array}{l}\text { Increase in mean annual costs ( } \$, G L M \text { coefficient) for } \\
\text { inpatient GLM }\end{array}$ & $1191(929,1453)$ & $<0.05$ \\
\hline & & & $\begin{array}{l}\text { Increase in mean annual costs (GLM coefficient) for } \\
\text { outpatient GLM }\end{array}$ & $248(211,284)$ & $<0.05$ \\
\hline Grun et al. [23] & 2003 & & $\begin{array}{l}\text { Adjusted difference of means cost per day ( , linear } \\
\text { regression) linear }\end{array}$ & $-0.8(-11.8,10.1)$ & 0.88 \\
\hline \multicolumn{6}{|l|}{ HD patients } \\
\hline \multirow[t]{2}{*}{ Hynes et al. [27] } & 2012 & $\mathrm{DM}$ & Adjusted annual cost difference (\$, GLM marginal effect) & $-1623(-14,973 ; 11,727)$ & 0.81 \\
\hline & & Complicated DM & & $8763(-10,331 ; 27,857)$ & 0.37 \\
\hline Icks et al. [31] & 2010 & None & Relative cost differences (euros, GLM) & $1.04(0.98,1.10)$ & \\
\hline \multirow[t]{2}{*}{ Mau et al. [33] } & 2010 & None & Case-mix-adjusted estimate & $0.0275(0.0014)$ & \\
\hline & & & Relative cost & 1.03 & $<0.001$ \\
\hline \multicolumn{6}{|l|}{ RRT patients } \\
\hline Joyce et al. [32] & 2004 & None & Adjusted annual cost difference ( $\$, G L M$ marginal effect ) & 42,361 & $<0.001$ \\
\hline
\end{tabular}

characteristics for cost modelling. Most studies did not consider comorbidities. Social, transport, and out-ofpocket expenses were not considered in the majority of studies. The diversity of comparators, populations, sources of costs, and the perspectives used in the various studies prevented us from performing a dollar-to-dollar comparison between the various studies or a metaanalysis.

There is evidence in the literature for a higher healthcare cost in the DM population regardless of their kidney disease status that is mainly driven by inpatient costs due to long hospital stays [39]. Yang et al. showed that the number of hospitalizations, and the mean length of hospital stay were the main drivers of the increased costs among DM patients [40]. Other studies in our review do not provide any insight into the drivers for higher costs for DM patients.

Higher costs for DM patients can also be explained by the number and total cost of medications, as patients with DM were more frequently prescribed cardiovascular, gastrointestinal, and endocrine drugs than non-DM patients treated by RRT [38], which is consistent with the metabolic complications intrinsic to DM and the high rate of vascular and neurological comorbidities in the DM population [41].

Wong et al. and Kao et al. [24, 34] reported lifetime costs of DM. In their study, the overall cost of RRT was higher for non-DM patients. However, when corrected by the expected years of life, the cost of RRT was higher in DM patients, as DM patients with ESKD are known to have a shorter life expectancy than non-DM patients $[15,42,43]$.

A more marked difference in costs between non-DM and DM patients was generally observed in the younger population, which could likely be explained by the lower rate of comorbidities in young non-DM patients. Younger patients are more likely to have type $1 \mathrm{DM}$; insulin therapy represents a high proportion of the cost of treatment for these patients. Younger patients have also been reported to have a higher first month cost when starting treatment as a result of training to perform PD independently and clinical evaluations for inclusion on transplant waiting lists [30]. This interesting point should be taken into account when performing future analyses of the costs associated with comorbidities and differences according to age groups and the reference time-points to be used. In the study by Bruns et al., the greatest difference was observed in an older age group (between the ages of 65 and 74). The distribution of the population in this study was slightly different from that of the general population, as outliers were likely to have an impact in the 65- to 74-year age group.

Only one of the studies provided data concerning the various types of living donor or cadaver transplant and graft loss. One study in our review included information on the cost for patients with or without DM related to the time since transplant. Costs were particularly high during the first year compared to the second year in 
both groups [29], supporting evidence that kidney transplantation is the RRT modality associated with the greatest economic benefits after the first year regardless of DM status [43].

\section{Conclusions}

We found an increased cost of RRT in patients with DM regardless of the treatment modality when compared to patients without DM. Given the increased prevalence of DM in the population, we can anticipate higher healthcare cost for this group of patients. The effects of presence of multiple comorbidities (in non-DM and DM patients), life expectancy, and specificity of type of dialysis treatment should be taken into account in future studies to obtain a better understanding of the effect of DM in RRT care. Additional information is also needed on indirect costs.

\section{Abbreviations}

CAPDTR: Continuous ambulatory peritoneal dialysis training; CHEE RS: Consolidated Health Economic Evaluation Reporting Standards; CKD: Chronic kidney disease; DM: Diabetes mellitus; ESKD: End-stage kidney disease; HD: Hemodialysis; PD: Peritoneal dialysis; RRT: Renal replacement therapy

\section{Acknowledgements}

We want to aknowledge CIFRE for providing us the oportunity to develop our researh.

\section{Authors' contributions}

CC developed the idea and performed the preliminary search and screening IV performed screening of abstracts and titles as well as full-text screening and data extraction and wrote the manuscript. CP and PT reviewed and edited the manuscript. All authors discussed and approved the manuscript.

\section{Funding}

No specific funding.

\section{Availability of data and materials}

The references used are available in the following databases: NHS Economic Evaluation Database, Health Technology Assessment (via EBM Reviews), Medline, Embase (via the Ovid platform), EconLit (via EBSCO), Cochrane library, APAIS Health (via Informit).

\section{Declarations}

Ethics approval and consent to participate

Not applicable.

\section{Consent for publication}

Not applicable.

\section{Competing interests}

The authors declare that they have no competing interests.

Received: 9 March 2021 Accepted: 14 May 2021

Published online: 31 May 2021

\section{References}

1. Kramer A, Pippias M, Noordzij M, Stel VS, Andrusev AM, Aparicio-Madre MI, et al. The European renal association - European dialysis and transplant association (ERA-EDTA) registry annual report 2016: a summary. Clin Kidney J. 2019 Oct 1;12(5):702-20. https://doi.org/10.1093/ckj/sfz011.

2. Wang V, Vilme H, Maciejewski ML, Boulware LE. The economic burden of chronic kidney disease and end-stage renal disease. Semin Nephrol. 2016 Jul;36(4):319-30. https://doi.org/10.1016/j.semnephrol.2016.05.008.
3. Kramer A, Stel V, Zoccali C, Heaf J, Ansell D, Gronhagen-Riska C, et al. An update on renal replacement therapy in Europe: ERA-EDTA registry data from 1997 to 2006. Nephrol Dial Transplant. 2009 Dec 1;24(12):3557-66. https://doi.org/10.1093/ndt/gfp519.

4. ERA-EDTA Registry Annual Report 2017. 2017;152.

5. Hallan SI, Dahl K, Oien CM, Grootendorst DC, Aasberg A, Holmen J, et al. Screening strategies for chronic kidney disease in the general population: follow-up of cross sectional health survey. BMJ. 2006 Nov 18;333(7577):1047. https://doi.org/10.1136/bmj.39001.657755.BE.

6. 2020 USRDS Annual Data Report: Epidemiology of kidney disease in the United States. Bethesda;: National Institutes of Health, National Institute of Diabetes and Digestive and Kidney Diseases; 2020.

7. USRDS. US Renal Data System 2019 Annual Data Report: epidemiology of kidney disease in the United States. 2019.

8. Assurance Maladie. Améliorer la qualité du système de santé et maîtriser les dépenses 2 juillet 2015 Propositions de l'Assurance Maladie pour 2016. 2015 juillet. 2015.

9. Tataradze A, Managadze G, Beglarashvili L, Kipshidze N, Managadze L, Chkhotua A. Comparative costs of different renal replacement therapies in lower middle income countries on the example of Georgia. Int I Clin Med. 2016;07(07):437-44. https://doi.org/10.4236/ijcm.2016.77046.

10. Ceretta ML, Noordzij M, Luxardo R, De Meester J, Abad Diez JM, Finne P, et al. Changes in co-morbidity pattern in patients starting renal replacement therapy in Europe-data from the ERA-EDTA registry. Nephrol Dial Transplant. 2018;33(10):1794-804. https://doi.org/10.1093/ndt/gfx355.

11. Li B, Cairns J, Fotheringham J, Tomson C, Forsythe J, Watson C, et al. Understanding cost of care for patients on renal replacement therapy: looking beyond fixed tariffs. Nephrol Dial Transplant. 2015;30(10):1726-34. https://doi.org/10.1093/ndt/gfv224.

12. Masakane I, Taniguchi M, Hasegawa T, Nakai S, Goto S, Wada A, et al. Annual dialysis data report 2017, JSDT renal data registry. Ren Replace Ther. 2019;5(1):53

13. Burrows NR, Hora I, Geiss LS, Gregg EW, Albright A. Incidence of endstage renal disease attributed to diabetes among persons with diagnosed diabetes - United States and Puerto Rico, 2000-2014. MMWR Morb Mortal Wkly Rep. 2017;66(43):1165-70. https://doi.org/10.1 5585/mmwr.mm6643a2.

14. Sørensen VR, Mathiesen ER, Watt T, Bjorner JB, Andersen MVN, FeldtRasmussen B. Diabetic patients treated with dialysis: complications and quality of life. Diabetologia. 2007;50(11):2254-62. https://doi.org/10.1007/ s00125-007-0810-1.

15. Soleymanian T, Kokabeh Z, Ramaghi R, Mahjoub A, Argani H. Clinical outcomes and quality of life in hemodialysis diabetic patients versus nondiabetics. Journal of Nephropathology. 2017;

16. Arsalan W, Syed AHB, Sidra B, Ayyaz AK. Quality of life in diabetic and non diabetic patients on hemodialysis therapy. J Diabetes Endocrinol. 2014;5(2): 9-18. https://doi.org/10.5897/JDE2013.0068.

17. Zhou, Y., Abel, G.A., Hamilton, W., Pritchard-Jones, K., Gross, C.P., Walter, F.M., Renzi, C., Johnson, S., McPhail, S., Elliss-Brookes, L. and Lyratzopoulos, G. Diagnosis of cancer as an emergency: a critical review of current evidence. Nat Rev Clin Oncol. 2016/11/03 ed. 2017 14(1):45-56.

18. Gilbertson DT, Liu J, Xue JL, Louis TA, Solid CA, Ebben JP, et al. Projecting the number of patients with end-stage renal disease in the United States to the year 2015. J Am Soc Nephrol. 2005;16(12):3736-41. https://doi.org/10.1 681/ASN.2005010112.

19. Bongiovanni I, Couillerot-Peyrondet A-L, Sambuc C, Dantony E, Elsensohn M-H, Sainsaulieu Y, et al. Évaluation médico-économique des stratégies de prise en charge de l'insuffisance rénale chronique terminale en France. Néphrologie Thérapeutique. 2016;12(2):104-15. https://doi.org/10.1016/j. nephro.2015.10.004

20. Tan SS, Rutten FFH, van Ineveld BM, Redekop WK, Hakkaart-van RL. Comparing methodologies for the cost estimation of hospital services. Eur J Health Econ. 2009;10(1):39-45. https://doi.org/10.1007/s10198-0080101-X.

21. Larg A, Moss JR. Cost-of-illness studies: a guide to critical evaluation. PharmacoEconomics. 2011;29(8):653-71. https://doi.org/10.2165/11588380000000000-00000.

22. Li B, Cairns J, Fotheringham J, Ravanan R, Ravanan R. Predicting hospital costs for patients receiving renal replacement therapy to inform an economic evaluation. Eur J Health Econ. 2016;17(6):659-68. https://doi.org/1 0.1007/s10198-015-0705-x 
23. Grun RP. Costs of dialysis for elderly people in the UK. Nephrol Dial Transplant. 2003;18(10):2122-7. https://doi.org/10.1093/ndt/ gfg354.

24. Kao T-W, Chang Y-Y, Chen P-C, Hsu C-C, Chang Y-K, Chang Y-H, et al. Lifetime costs for peritoneal dialysis and hemodialysis in patients in Taiwan. Perit Dial Int J Int Soc Perit Dial. 2013;33(6):671-8. https://doi.org/10.3747/ pdi.2012.00081.

25. Su B-G, Tsai K-L, Yeh S-H, Ho Y-Y, Liu S-Y, Rivers PA. Risk factor and cost accounting analysis for dialysis patients in Taiwan. Health Serv Manag Res. 2010;23(2):84-93. https://doi.org/10.1258/hsmr.2009. 009017.

26. Yang W-C, Hwang S-J, Chiang S-S, Chen H-F, Tsai S-T. The impact of diabetes on economic costs in dialysis patients: experiences in Taiwan. Diabetes Res Clin Pract. 2001;54:47-54. https://doi.org/10.1016/S0168-822 7(01)00309-6.

27. Hynes DM, Stroupe KT, Fischer MJ, Reda DJ, Manning W, Browning MM, et al. Comparing VA and private sector healthcare costs for end-stage renal disease. Med Care. 2012;50(2):161-70. https://doi.org/10.1097/MLR.0b013e31 822dcf15.

28. Bruns F, Seddon P, Saul P, Zeidel M. The cost of caring for end-stage kidney disease patients: an analysis based on hospital financial transaction records. American Society of Nephrology. 1997;12.

29. Salonen $T$, Reina $T$, Oksa $H$, Sintonen $H$, Pasternack A. Cost analysis of renal replacement therapies in Finland. Am J Kidney Dis. 2003 Dec;42(6):1228-38. https://doi.org/10.1053/j.ajkd.2003.08.024.

30. Couillerot-Peyrondet A-L, Sambuc C, Sainsaulieu Y, Couchoud C, Bongiovanni-Delarozière I. A comprehensive approach to assess the costs of renal replacement therapy for end-stage renal disease in France: the importance of age, diabetes status, and clinical events. Eur J Health Econ. 2017;18(4):459-69. https://doi.org/10.1007/s10198-0160801-6.

31. Icks A, Buckhard H, Afschin G, Chernyak N, Rathmann W, Giani G, et al. Cost of dialysis-a regional population-based analysis. Nephrology Dialysis Transplantation. 2009;

32. Joyce AT, lacoviello JM, Nag S, Sajjan S, Jilinskaia E, Throop D, et al. Endstage renal disease-associated managed care costs among patients with and without diabetes. Diabetes Care. 2004;27(12):2829-35. https://doi.org/1 0.2337/diacare.27.12.2829.

33. Mau L-W, Liu J, Qiu Y, Guo H, Ishani A, Arneson TJ, et al. Trends in patient characteristics and first-year medical costs of older incident hemodialysis patients, 1995-2005. Am J Kidney Dis. 2010;55(3):549-57. https://doi.org/10.1 053/j.ajkd.2009.11.014.

34. Wong G, Howard K, Chapman JR, Chadban S, Cross N, Tong A, et al. Comparative survival and economic benefits of deceased donor kidney transplantation and dialysis in people with varying ages and co-morbidities. van Baal PHM, editor. PLoS ONE. 2012 Jan 18;7(1): e29591.

35. Ghoddousi K, Ramezani MK, Assari S, Lankarani MM, Amini M, Khedmat H, et al. Primary kidney disease and post-renal transplantation hospitalization costs. Transplant Proc. 2007;39(4):962-5. https://doi.org/10.1016/j.tra nsproceed 2007.03.007.

36. DG Smith, LC Harlan, VM Hawthorne. The charges for ESRD treatment of diabetics. 1989.

37. Woodward RS, Flore MC, Machnicki G, Brennan DC. The long-term outcomes and costs of diabetes mellitus among renal transplant recipients: tacrolimus versus cyclosporine. Value Health. 2011;14(4):443-9. https://doi. org/10.1016/j.jval.2010.10.030.

38. Manley, HJ, Cannella, CA. Nondialysis (home) medication utilization and cost in diabetic and nondiabetic hemodialysis patients. Nephrology News \& Issues. 2005

39. Cheng S-W, Wang C-Y, Ko Y. Costs and length of stay of hospitalizations due to diabetes-related complications. J Diabetes Res. 2019:2019:1-6. https://doi.org/10.1155/2019/2363292.

40. Yang M, Fox $\mathrm{CH}$, Vassalotti J, Choi M. Complications of progression of CKD. Adv Chronic Kidney Dis. 2011;18(6):400-5. https://doi.org/10.1053/j.ackd.2 011.10.001.

41. Webb L, Gilg J, Feest T, Fogarty D. Chapter 4: comorbidities and current smoking status amongst patients starting renal replacement therapy in England, Wales and Northern Ireland from 2008 to 2009. Nephron Clin Pract. 2011;119(s2):c85-96. https://doi.org/10.1159/000331 754.
42. Couchoud C, Stengel B, Landais P, Aldigier J-C, de Cornelissen F, Dabot Cet al. The renal epidemiology and information network (REIN): a new registry for end-stage renal disease in France. Nephrol Dial Transplant 2006; 21(2):411-418, DOl: https://doi.org/10.1093/ndt/gfi198.

43. Vijayan M, Radhakrishnan S, Abraham G, Mathew M, Sampathkumar K, Mancha NP. Diabetic kidney disease patients on hemodialysis: a retrospective survival analysis across different socioeconomic groups. Clin Kidney J. 2016;9(6):833-8. https://doi.org/10.1093/ckj/sfw069.

\section{Publisher's Note}

Springer Nature remains neutral with regard to jurisdictional claims in published maps and institutional affiliations.
Ready to submit your research? Choose BMC and benefit from:

- fast, convenient online submission

- thorough peer review by experienced researchers in your field

- rapid publication on acceptance

- support for research data, including large and complex data types

- gold Open Access which fosters wider collaboration and increased citations

- maximum visibility for your research: over $100 \mathrm{M}$ website views per year

At BMC, research is always in progress.

Learn more biomedcentral.com/submissions 